\title{
Wash Dosage Form
}

National Cancer Institute

\section{Source}

National Cancer Institute. Wash Dosage Form. NCI Thesaurus. Code C64903.

A solution or suspension composed of active and/or inert ing redient(s) and intended for administration as an irrig ant and cleanser. 